\title{
FENOMENA PENGELOLAAN DAN PELAPORAN MASJID JOGOKARIYAN YOGYAKARTA PADA ASPEK MENTAL, FISIK DAN SPIRITUAL
}

\author{
Laili Nashari Pramesvari* ${ }^{*}$ \\ Magister Akuntansi, Fakultas Ekonomi dan Bisnis, Universitas Jenderal Soedirman, Indonesia \\ *Email corresponding author: pramesvarilailinashari@gmail.com
}

\begin{abstract}
Abstrak
Penelitian ini bertujuan untuk menganalisis pertanggungjawaban pengelolaan masjid Jogokariyan dari aspek mental, fisik dan spiritual. Metode penelitian yang digunakan adalah kualitatif studi kasus dengan mengangkat fenomena pengelolaan dan pelaporan pada masjid Jogokariyan di Yogyakarta. Aspek fisik (kinerja keuangan) diukur dengan kesesuaian laporan penerapan PSAK 45 (Akuntansi Perusahaan Nirlaba) dan PSAK 109 (Akuntansi Zakat, Infak dan Sedekah). Aspek mental (kinerja mental) diukur dengan ketercapaian program menggunakan indikator akuntabilitas menurut Ellwood yaitu akuntabilitas hukum \& kejujuran, akuntabilitas proses, akuntabilitas program dan akuntabilitas kebijakan.Aspek spiritual diukur dengan penerapan etika syariah pada diri pengelola masjid.

Peneliti menggunakan teknik analisis data menurut Miles and Huberman dengan melakukan pengumpulan data, reduksi data, penyajian dan penarikan kesimpulan. Pengumpulan data dilakukan dengan cara observasi, wawancara (takmir dan jamaah) dan dokumentasi. Teknik reduksi data menggunakan software QSR Nvivo untuk mengolah data hasil wawancara.Uji keabsahan data menggunakan uji kepercayaan, uji keteralihan, kebergantungan dan kepastian. Uji kepercayaan menggunakan metode triangulasi sumber (takmir dan jamaah), dan triangulasi teknik (observasi, wawancara dan dokumentasi).

Berdasarkan hasil penelitian, pertanggungjawaban pengelolaan masjid Jogokariyan pada aspek mental telah terpenuhi dengan tercapai-nya program-program sesuai aturan yang ada. Laporan setiap program dimuat di bulentin masjid yang diterbitkan di Idul Fitri dan Idul Adha. Pertanggungjawaban pengelolaan masjid pada aspek fisik memang belum sepenuhnya terpenuhi. Takmir tidak mengenal PSAK 45 maupun PSAK 109. Bendahara sebatas mencatat arus kas masuk dan kas keluar saja, meskipun sudah sangat jelas dan transparan.Tercapainya program-program masjid juga didukung dengan tercapainya pertanggungjawaban pengelolaan masjid pada aspek spiritual. Takmir dengan sepenuh hati semata-mata karena Allah melayani jamaah. Mereka bekerja tidak mengharapkan imbalan apapun di dunia melainkan mendapat imbalan berupa pahala dari Allah SWT. Ketiga aspek sangatlah penting, kinerja mental dapat tercapai ketika adanya keseimbangan antara kinerja fisik dan kinerja spiritual.

Implikasi dari kesimpulan di atas adalah agar kedepan dapat dibuat laporan ketercapaian program masjid yang memuat prosentase ketercapaiannya. Sehingga laporan tersebut dapat menjadi acuan untuk menjalankan program selanjutnya dan dapat menemukan solusi atas hambatan yang ada. Takmir masjid juga sebaiknya mengikuti pelatihan akuntansi untuk memperbaiki laporan keuangan yang dibuat karena masjid bukan hanya organisasi nirlaba saja melainkan juga sebuah entitas bisnis. Perlu adanya pelaporan keuangan yang baik sesuai dengan standar akuntansi yang berlaku agar kelangsungan usaha masjid dapat berjalan lancar. Untuk aspek spiritual alangkah lebih baik jika dibuat laporan akuntansi syariah yang berisi Laporan Komitmen Tauhid, Laporan Rahmat Allah dan Laporan Amanah Allah (Triyuwono, 2011). Laporan tersebut berfungsi sebagai doa dan zikir yang dapat mengubah sirkuit sistem syaraf otak para pengguna untuk membentuk citra Allah dan perilaku positif seperti yang terkandung dalam laporan tersebut.

Kata Kunci: Pertanggungjawaban, Masjid, Mental, Fisik, Spiritual.
\end{abstract}

\begin{abstract}
This study aims to analyze the responsibility of managing the Jogokariyan mosque from mental, physical and spiritual aspects. The research method used is a qualitative case study by raising the phenomenon of management and reporting at the Jogokariyan mosque in Yogyakarta. The physical aspect (financial performance) is measured by the suitability of the report on the application of PSAK 45 (Accounting for Non-profit Companies) and PSAK 109
\end{abstract}



Spiritual

(Accounting for Zakat, Charity and Alms). Mental aspects (mental performance) are measured by program achievements using accountability indicators according to Ellwood, namely legal \& honesty, process accountability, program accountability and policy accountability. The spiritual aspect is measured by the application of sharia ethics to the mosque manager.

Researcher used data analysis techniques according to Miles and Huberman by collecting data, reducing data, presenting and drawing conclusions. Data collection is done by observation, interviews (takmir and pilgrims) and documentation. Data reduction techniques use the Nvivo QSR software to process the interview data. Test the validity of the data using a test of trust, test the reliability, dependability and certainty. Trust testing uses source triangulation methods (takmir and pilgrims), and technical triangulation (observation, interviews and documentation).

Based on the results of the study, the responsibility of managing the Jogokariyan mosque on the mental aspect has been fulfilled with the achievement of programs according to existing rules. Reports of each program are published in the mosque bulletin published in Eid al-Fitr and Eid al-Adha. The responsibility for managing the mosque on the physical aspect is not yet fully fulfilled. Takmir is not familiar with PSAK 45 or PSAK 109. The treasurer is limited to recording cash inflows and cash outflows, even though it is very clear and transparent. The achievement of mosque programs is also supported by the achievement of accountability in managing the mosque on the spiritual aspect. Takmir wholeheartedly solely because Allah serves worshipers. They do not expecting any reward in the world but get a reward in the form of a reward from Allah SWT. These three aspects are very important, mental performance can be achieved when there is a balance between physical performance and spiritual performance.

The implication of the above conclusion is that in the future a mosque program achievement report can be made which contains a percentage of its achievements. So that the report can be a reference to run the next program and can find solutions to existing obstacles. Takmir mosque should also take accounting training to improve financial reports made because the mosque is not only a non-profit organization but also a business entity. There is a need for good financial reporting in accordance with applicable accounting standards so that the business continuity of the mosque can run smoothly. For the spiritual aspect it would be better if a sharia accounting report is made which contained a report on the Commitment of Tawheed, the Report of God's Grace and the Report of Allah's Trust (Triyuwono, 2011). The report functions as a prayer and remembrance that can change the nervous system of the user's brain to form the image of God and positive behavior as contained in the report.

Keywords: Responsibility, Mosque, Mental, Physical, Spiritual

\section{PENDAHULUAN}

Indonesia merupakan negara dengan populasi umat muslim terbesar di dunia. Sensus penduduk di Indonesia tahun 2010 menyatakan bahwa sebesar 87,18\% jiwa atau setara 207.176.162 penduduk di Indonesia adalah beragama Islam (www.bps.go.id). Besarnya prosentase penduduk yang beragama Islam berbanding lurus dengan banyaknya masjid di Indonesia. Hingga tahun 2019 jumlah masjid dan musala yang terdaftar di Kementrian Agama Republik Indonesia adalah 546.043 (simas.kemenag.go.id).

Masjid bukan hanya tempat yang digunakan untuk ritual ibadah saja, tetapi juga sebagai sarana umat muslim untuk melakukan aktivitas sosial, pendidikan dan sebagai tempat pemersatu umat. Dewan Masjid Indonesia menjelaskan fungsi masjid yang pertama sebagai madlah atau tempat ibadah dalam arti sempit seperti sholat dan mengaji sekaligus menjadi ghairu madlah atau tempat ibadah secara lebih luas seperti tempat memperkuat interaksi sosial masyarakat. Kedua, masjid sebagai wadah masyarakat melalui sarana dan prasarana yang ada. Masjid digunakan sebagai pusat pendidikan, pengajaran dan pengembangan ilmu, pusat pengumpulan dan distribusi zakat, infaq, dan shodaqoh, tempat beristirahat kaum musafir, dan sebagainya. Ketiga, masjid sebagai pusat pemersatu dan pusat komunikasi umat. Segala macam informasi dan kegiatan masyarakat Islam dapat dilakukan di masjid.

Dana-dana yang diperoleh dari berbagai sumber di atas digunakan untuk membiayai aktivitas masjid, pengadaan sarana dan prasarana serta pengembangan masjid. Dana itu dikeluarkan untuk 
membiayai kegiatan rutin, mengurus masjid, memelihara/ merawatnya. Kegiatan masjid tentu terlaksana dengan baik jika tersedia dana dalam jumlah yang mencukupi. Dana yang terkumpul juga harus dikelola dengan baik agar dapat memenuhi segala macam kebutuhan dan kegiatan masjid. Untuk itu, penting adanya sebuah pertanggungjawaban dari pengelola/takmir masjid atas dana yang dikelola. Pertanggungjawaban yang dilakukan oleh para takmir masjid tidak hanya kepada manusia saja secara habluminannas (donatur dan jamaah) tetapi yang utama adalah pertanggungjawaban kepada Allah secara habluminallah. Secara habluminannas adalah dalam hubungan antar sesama manusia itu sendiri yang dalam hal ini melibatkan aspek mental. Secara habluminallah adalah dalam hubungan antara manusia dengan Allah SWT yang dalam hal ini melibatkan aspek spiritual. Aspek mental di sini sebagai aspek yang menjembatani jalannya aspek fisik dan aspek spiritual.

Pertanggungjawaban pada aspek fisik yang dliakukan oleh para takmir masjid adalah membuat laporan keuangan masjid berdasarkan standar yang telah dibuat. Ikatan Akuntansi Indonesia (IAI) membuat Pernyataan Standar Akuntansi Keuangan (PSAK) No.45 yang tujuannya adalah untuk mengatur pelaporan keuangan organisasi nirlaba. IAI juga mengeluarkan Pernyataan Standar Akuntansi Keuangan (PSAK) No.109 tentang akuntasi Zakat dan Infak/Sedekah untuk menyeragamkan pelaporan, dan kesederhanaan pencatatan Zakat dan Infak/Sedekah, sehingga publik dapat membaca laporan akuntansi pengelola zakat serta mengawasi pengelolaannya.

Pertanggungjawaban pada aspek mental dapat dilihat dari berbagai jenis pertanggungjawaban (Ellwood, 1993) dalam Mardiasmo (2002) yaitu pertanggungjawaban kejujuran dan pertanggungjawaban hukum (accountability for probity and legality), pertanggungjawaban proses (process accountability), pertanggungjawaban program (program accountability) dan pertanggungjawaban kebijakan (policy accountability) terkait dengan pertanggungjawaban

Pertanggungjawaban pada aspek spiritual dapat dilihat dengan perwujudan etika syariah berdasarkan nilai-nilai ajaran Islam secara menyeluruh berlandaskan Al-Qur'an dan Hadist. Jika dari perspektif ajaran etika (akhlak) dalam Islam pada prinsipnya manusia dituntut untuk berbuat baik pada dirinya sendiri, disamping kepada sesama manusia, alam lingkungannya dan kepada Tuhan selaku pencipta-Nya.

Penelitian ini bertujuan untuk mengungkap pengelolaan pelaporan masjid dari aspek mental, fisik dan spiritual di salah satu masjid besar yang dinobatkan sebagai Masjid Percontohan di Indonesia oleh Kementrian Agama RI pada tahun 2016 yaitu Masjid Jogokariyan. Masjid ini memiliki visi mewujudkan masyarakat yang sejahtera lahir bathin yang diridhoi Allah melalui kegiatan kemasyarakatan yang berpusat di masjid, sehingga fungsi masjid di zaman Rasulullah dapat terwujud kembali. Peneliti memilih Masjid Jogokariyan sebagai objek penelitian karena masjid ini memiliki banyak keunikan yang tidak dimiliki oleh masjid-masjid lain di Indonesia. Masjid Jogokariyan memiliki misi untuk memakmurkan masjid bukan hanya fokus dari segi fisik bangunan saja tapi yang utama adalah pada jamaahnya.

\section{TELAAH PUSTAKA}

\section{Akuntabilitas}

Akuntabilitas merupakan suatu cara pertanggungjawaban manajemen atau penerima amanah kepada pemberi amanah atas pengelolaan sumber-sumber daya yang dipercayakan kepadanya baik secara vertikal maupun secara horizontal. Dalam definisi tradisional, Akuntabilitas menurut Benveniste (1991) adalah istilah umum untuk menjelaskan bahwa organisasi atau perusahaan sudah memenuhi misi yang mereka emban sebagaimana dikutip Arifiyadi (2008).

Akuntabilitas juga tersirat dalam Al-Qur'an surat Al Baqarah 282, yang mewajibkan pencatatan dari setiap aktivitas transaksi. Pencatatan transaksi ini akan memberikan informasi dan akuntabilitas (kekuatan untuk dipertanggungjawabkan) terhadap kondisi riil yang ada kepada publik sebagai obyek, pihak yang juga punya hak untuk mempertanyakannya (Adlan, 2010)

\section{Aspek Akuntabilitas}

Berbagai bentuk akuntabilitas di atas melibatkan aspek fisik, mental dan spiritual (Triyuwono dan Roekhuddin, 2000). Aspek fisik dalam akuntabilitas di atas adalah dalam bentuk laporan keuangan dan laporan lainnya yang secara fisik dapat terlihat dan cenderung bersifat kuantitatif. Akuntabilitas yang hanya melibatkan aspek fisik saja cenderung bebas nilai sehingga penilaiannya 
hanya untung/ rugi secara material dan cenderung kurang humanis. Agar tidak bebas nilai, aspek fisik tersebut harus ditunjang dengan aspek mental dan spiritual. Aspek mental meliputi nilainilai humanis seseorang yang etis sehingga mengesampingkan ego dan lebih bersifat altruistis. Aspek mental dalam akuntabilitas diwujudkan dalam bentuk laporan kualitatif. Laporan kualitatif yang dimaksud berupa laporan pencapaian program-program yang telah direncanakan, ketaatan pada aturan yang ditetapkan atau penjelasan atas pencapaian materiil dalam laporan kuantitatif yang ada. Aspek spiritual berkaitan dengan aspek spiritual yang menekankan pada hubungan manusia dengan Tuhan. Perasaan yakin dan takut pada Tuhan akan berpengaruh pada mental dan perilaku seseorang karena ia merasa selalu diawasi.

\section{Dimensi Akuntabilitas Publik}

Dimensi Akuntabilitas Publik yang harus dilakukan oleh organisasi sektor publik menurut Elwood (1993). Akuntabilitas Hukum dan Kejujuran adalah akuntabilitas lembaga-lembaga publik untuk berperilaku jujur dalam bekerja dan menaati ketentuan hukum yang berlaku. Penggunaan dana publik harus dilakukan secara benar dan telah mendapatkan otorisasi. Akuntabilitas hukum berkaitan dengan kepatuhan terhadap hukum dan peraturan lain yang disyaratkan dalam menjalankan organisasi, sedangkan akuntabilitas kejujuran berkaitan dengan penghindaran penyalahgunaan jabatan, korupsi dan kolusi. Akuntabilitas Program berkaitan dengan pertimbangan apakah tujuan yang ditetapkan dapat dicapai atau tidak, dan apakah telah mempertimbangkan alternatif program yang memberikan alternatif program yang memberikan hasil yang optimal dengan biaya yang minimal. Dengan kata lain akuntabilitas program berarti bahwa program-program organisasi hendaknya merupakan program yang bermutu yang mendukung strategi dan pencapaian misi, visi, dan tujuan organisasi. Akuntabilitas Proses merupakan pertanggungjawaban lembaga-lembaga publik untuk menggunakan dana publik secara ekonomis, efisien, dan efektif, tidak ada pemborosan dan kebocoran dana, serta korupsi. Akuntabilitas Finansial ini sangat penting karena menjadi sorotan utama masyarakat. Akuntabilitas ini mengaharuskan lembaga-lembaga publik untuk membuat laporan keuangan untuk menggambarkan kinerja finansial organisasi kepada pihak luar. Akuntabilitas Kebijakan terkait dengan pertanggungjawaban lembaga publik atas kebijakan-kebijakan yang diambil. Lembaga-lembaga publik hendaknya dapat mempertanggungjawabkan kebijakan yang telah ditetapkan dengan mempertimbangkan dampak di masa depan. Dalam membuat kebijakan harus dipertimbangkan apa tujuan kebijakan tersebut, mengapa kebijakan itu diambil siapa sasarannya, pemangku kepentingan mana yang akan terpengaruh dan memperoleh manfaat dan dampak (negatif) atas kebijakan tersebut.

\section{PSAK 45}

Pernyataan Standar Akuntansi Keuangan no. 45 merupakan pedoman yang dibuat oleh Ikatan Akuntan Indonesia yang tujuannya adalah untuk mengatur pelaporan keuangan organisasi nirlaba. Dengan adanya standar pelaporan, diharapkan laporan keuangan organisasi nirlaba dapat lebih mudah dipahami, memiliki relevansi, dan memiliki daya banding yang tinggi. Menurut PSAK NO. 45 tahun 2015 Laporan keuangan organisasi nirlaba meliputi laporan posisi keuangan pada akhir periode laporan, laporan aktivitas serta laporan arus kas untuk suatu periode pelaporan, dan catatan atas laporan keuangan. Unsur-unsur dalam laporan keuangan organisasi nirlaba berdasarkan PSAK No. 45, meliputi: Laporan Posisi Keuangan, Laporan Aktivitas, Laporan Arus Kas dan Catatan Atas Laporan Keuangan.

\section{PSAK 109}

Pernyataan Standar Akuntansi Keuangan Nomor 109 tentang Akuntansi Zakat dan Infak/Sedekah bertujuan untuk mengatur pengakuan, pengukuran, penyajian dan pengungkapan transaksi zakat dan infaq/sedekah. Pernyataan ini berlaku untuk amil yang menerima dan menyalurkan zakat dan infak/sedekah (IAI, 2015). Unsur-unsur dalam laporan keuangan organisasi nirlaba berdasarkan PSAK No. 45, meliputi: Laporan Posisi Keuangan, Laporan Perubahan Dana, Laporan Perubahan Aset Kelolaan, Laporan Arus Kas Entitas, Catatan Atas Laporan Keuangan. 


\section{Etika Syariah}

Etika Syariah / Etika Bisnis Islam adalah norma-norma etika yang berbasiskan Al-Quran dan Hadist yag harus dijadikan acuan oleh siapapun dalam aktivitas bisnisnya (Djakfar, 2012). Dalam hal ini, takmir masjid mengelola masjid baik dalam hal keuangan atau lainnya harus berlandaskan dengan etika secara Islam.Etika bisnis Islam adalah akhlak dalam menjalankan bisnis sesuai dengan nilai-nilai Islam, sehingga dalam melaksanakan bisnisnya tidak perlu ada kekhawatiran, sebab sudah diyakini sebagai sesuatu yang baik dan benar (Hasan, 2010).

Dilihat dari perspektif ajaran etika (akhlak) dalam Islam pada prinsipnya manusia dituntut untuk berbuat baik pada dirinya sendiri, disamping kepada sesama manusia, alam lingkungannya dan kepada Tuhan selaku pencipta-Nya. Oleh karena itu, untuk bisa berbuat baik pada semuanya itu, manusia hendaknya memperhatikan keesaan Tuhan (tauhid), tanggung jawab (responsibility) dan kebajikan (ihsan).

\section{METODE PENELITIAN}

\section{Teknis Analisis Data}

Menurut Milles and Huberman, analisis data tertata dalam situs ditegaskan bahwa kolom pada sebuah matriks tata waktu disusun dengan jangka waktu, dalam susunan tahapan, sehingga dapat dilihat kapan gejala tertentu terjadi. Prinsip dasarnya adalah kronologi.

Untuk menyajikan data agar mudah dipahami, maka langkah-langkah anlisis data yang digunakan dalam penelitian ini adalah Analysis Interactive Model dari Miles dan Huberman, yang membagi langkah-langkah dalam kegiatan analisis data dengan beberapa bagian yaitu pengumpulan data (data collection), reduksi data (data reduction), penyajian data (data display), dan penarikan kesimpulan atau verifikasi (conclutions). Pengumpulan data hasil wawancara, hasil observasi, dan berbagai dokumen berdasarkan kategorisasi yang sesuai dengan masalah penelitian yang kemudian dikembangkan penajaman data melalui pencarian data selanjutnya.

Reduksi data adalah suatu bentuk analisis yang menajamkan, menggolongan, mengarahkan, membuang data yang tidak perlu dan mengorganisasi data dengan cara sedemikian rupa sehingga simpulan final dapat ditarik dan diverifikasi (Miles dan Huberman, 2007). Menurut Mantja Harsono (2008), reduksi data berlangsung secara terus menrus sepanjang penelitian belum diakhiri. Produk dari reduksi data adalah berupa ringkasan dari catatan lapangan, baik dari catatan awal, perluasan, maupun penambahan.Untuk memudahkan tahapan pengolahan data temuan penelitian ini peneliti menggunakan perangkat lunak (software) yang dikhususkan untuk mengolah data dan informasi pada metodologi kualitatif. QSR NVIVO merupakan software yang sudah teruji dan handal dalam mengelola data dan informasi dalam metodologi kualitatif yang terus dikembangkan dari sejak Versi 2 hingga sekarang.

Penyajian Data adalah suatu rangkaian organisasi informasi yang memungkinkan kesimpulan riset dapat dilakukan. Penyajian data dimaksudkan untuk menemukan pola-pola yang bermakna serta memberikan kemungkinan adanya penarikan simpulan serta memberikan tindakan (Miles dan Huberman, 2007). Menurut Sutopo dalam Harson (2008) menyatakan bahwa sajian data berupa narasi kalimat, gambar/skema, jaringan kerja dan tabel sebagai narasinya.

Penarikan kesimpulan merupakan bagian dari sutu kegiatan konfigurasi yang utuh (Miles dan Huberman, 2007). Kesimpulan juga diverifikasi selama penelitian berlangsung. Kesimpulan ditarik semenjak peneliti menyususn pencatatan, polapola, pernyataan-pernyataan, konfigurasi, arahan sebab akibat, dan berbagai proposisi (Harsono, 2008).

\section{Informan Penelitian}

Informan penelitian adalah orang atau pihak yang dibutuhkan untuk memberikan informasi tentang situasi dan kondisi latar belakang penelitian. Informan yang dipilih adalah orang yang benar-benar mengetahui permasalahan yang akan diteliti dan orang yang sedang menduduki jabatan yang sesuai dengan informasi yang ingin digali. Informasi yang diperoleh dari informan berupa hasil wawancara. Para informan, mereka tidak hanya sekedar tahu dan dapat memberikan informasi, tetapi juga telah menghayati atau memahami dengan sungguh-sungguh sebagai akibat dari keterlibatannya yang cukup lama dengan lingkungan dan kegiatan yang bersangkutan. Informan pada penelitian ini yaitu para pengurus Masjid Jogokariyan, akademisi dan jamaah masjid baik dari sekitar Masjid Jogokariyan ataupun dari luar kota. 


\section{Uji Keabsahan Data}

Pengujian keabsahan data menggunakan empat criteria sebagaimana yang dikemukakan oleh Sugiyono (2010), yaitu: kredibilitas (credibility), keteralihan (transferability), kebergantungan/reliabilitas (dependability), dan kepastian/dapat dikonfirmasi (confirmability). Uji credibility atau validitas internal merupakan uji kepercayaan terhadap data hasil penelitian kualitatif yang dilakukan dengan perpanjangan pengamatan, peningkatan ketekunan dalam penelitian, triangulasi, diskusi dengan teman sejawat, analisis kasus negatif, dan member check. Ada dua jenis triangulasi yaitu triangulasi sumber dan triangulasi teknik.

Uji Keteralihan (transferability), pada dasarnya merupakan validitas eksternal pada penelitian kualitatif. Transferability perlu dilakukan orang lain yang telah mempelajari laporan peneliti (Sutama, 2010). Orang lain, termasuk rekan-rekan peneliti, para pembimbing atau promoter, dan para penguji akan membandingkannya dengan kepustakaan, wacana, penelitian, dan pengalamannya masing-masing. Agar mereka itu memperoleh gambaran yang jelas, peneliti perlu menjelaskan latar dan adegan mengenai tempat gejala itu berlangsung dan diteliti teliti.

Dependability dalam penelitian kualitatif disebut reliabilitas. Suatu penelitian dikatakan dependability apabila orang lain dapat mengulangi atau mereplikasi proses penelitian tersebut. Dalam penelitian kualitatif, uji dependability dilakukan dengan cara malakukan audit terhadap keseluruhan proses penelitian. Caranya dilakukan oleh auditor yang independen atau pembimbing untuk mengaudit keseluruhan aktivitas peneliti dalam melakukan penelitian.

Confirmability atau konfirmabilitas merupakan serangkaian langkah untuk mendapatkan jawaban apakah ada keterkaitan antara data yang sudah diorganisasikan dalam catatan lapangan dengan materi-materi yang digunakan dalam audit trail (Harsono, 2008). Audit trail merupakan langkah diskusi analitik terhadap semua berkas data hasil penelitian, mulai berkas data penelitian sampai dengan transkip pelaporan. Secara lugas, konfirmabilitas dilakukan dengan konfirmasi informasi secara langsung kepada nara sumber dan menghubungkan perolehan informasi satu sama lain.

\section{HASIL PENELITIAN (INTERPRETASI)}

\section{Pertanggungjawaban Pengelolaan Masjid pada Aspek Mental}

Hasil reduksi terkait QSR Nvivo pada aspek mental sebagai berikut:

Gambar 1. Word Frequency Query QSR Nvivo pada aspek mental

Selanjutnya poin penting hasil reduksi dituliskan pada tabel 1.

Tabel 1. Poin penting hasil reduksi QSR Nvivo 12 menurut aspek mental

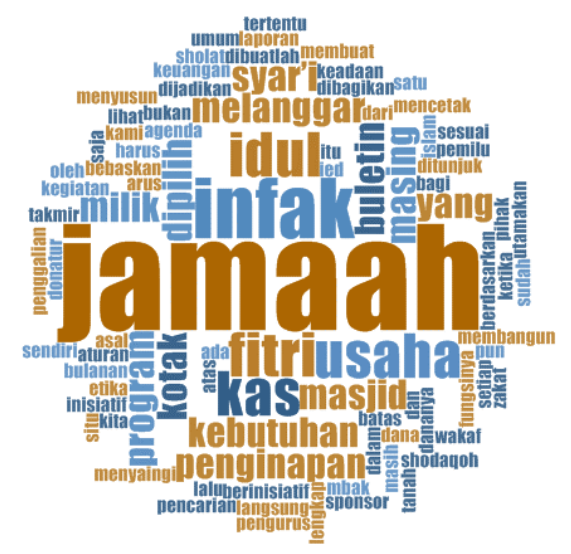




\begin{tabular}{ll}
\hline \multicolumn{1}{c}{ Indikator Ellwood (1993) } & \multicolumn{1}{c}{ Poin Penting } \\
\hline Akuntabilitas Kejujuran dan & Demokrasi pemilihan pengurus \\
Hukum & Penggalian dana dengan prinsip syar'i \\
\hline Akuntabilitas Program & $\begin{array}{l}\text { Orientasi kebutuhan jamaah } \\
\text { Progres program dalam bulletin }\end{array}$ \\
\hline \multirow{2}{*}{ Akuntabilitas Proses } & $\begin{array}{l}\text { Pemisahan kelompok kotak infak } \\
\text { Rekap arus kas bulanan }\end{array}$ \\
\hline \multirow{2}{*}{ Akuntabilitas Kebijakan } & $\begin{array}{l}\text { Usaha penginapan } \\
\text { Unit usaha bukan varian jamaah }\end{array}$ \\
\hline
\end{tabular}

Poin-poin pada Tabel 1 dapat diinterpretasikan bahwa takmir merupakan pelayan jamaah, bukan penguasa masjid. Poin 1-2 menunjukkan bahwa kaderisasi takmir berdasarkan pemilihan langsung yang dilakukan oleh masyarakat Jogokariyan, bukan atas dasar penunjukkan atau keturunan tertentu.Jadi jelas di sini tidak ada penguasaan dari pihak tertentu yang menentukan predikat takmir masjid. Takmir yang dipilih oleh masyarakat dibebaskan untuk berinisatif dalam pencarian sponsor untuk kegiatan terntentu selama masih dalam batas syar'i.

Poin 3-4 menunjukkan bahwa takmir merancang program-program masjid berdasarkan kebutuhan masyarakat Jogokariyan. Kebutuhan masyarakat didapatkan dengan adanya pemetaan jamaah. Pemetaan ini menghasilkan berbagai kondisi yang dialami oleh masing-masing rumah di Jogokariyan.Sehingga dibuatlah program sesuai dengan kondisi yang ada misalnya kursus sholat untuk para mualaf, atm beras untuk warga miskin, gerakan saldo mandiri untuk menutupi kebutuhan masjid yang sempat minus, dan lain-lain. Program-program yang ada tidak hanya dilaksanakan tapi juga dilaporkan progresnya oleh para takmir yang dimuat dalam bulletin Idul Fitri dan Idul Adha.

Poin 5-6 menunjukkan bahwa pelaksanaan program melibatkan pengelolaan dana baik dari internal (usaha masjid) dan eksternal (zakat, infak dan sedekah dari jamaah). Maka dibuatlah pemisahan pengelolaan dana dari masing-masing sumber. Pemisahan pengelolaan ini supaya uang yang masuk lebih jelas peruntukkannya.Setiap bulan juga selalu dibuat rekapan arus kas oleh bendahara dari rekapan kas masuk dan kas keluar mingguan yang dilaporkan oleh setiap penanggungjawab setiap hari Jum'at. Hal ini merupakan bentuk tanggungjawab takmir pada jamaah dan donator atas dana yang dikelolanya. Sehingga jamaah bisa memonitor dan mengevaluasi pengelolaan keuangan masjid.

Poin 7-8 menunjukkan bahwa meskipun masjid memiliki usaha penginapan untuk memenuhi kebutuhannya sendiri.Usaha tersebut bukan usaha yang menyaingi usaha milik jamaah.Jadi di sini takmir tidak memikirkan kelangsungan usaha masjid saja, melainkan usaha yang dimiliki oleh jamaah sekitar.

Hasil reduksi mengartikan bahwa takmir memprioritaskan masyarakat sebagai raja. Ibaratkan masjid sebagai sebuah toko yang memenuhi kebutuhan masyarakat, takmir adalah pelayan dan jamaah adalah tamu (rajanya). Takmir membuat program tidak berdasarkan kepentingan tertentu tetapi berdasarkan kondisi real masyarakat Jogokariyan.Untuk memenuhi kebutuhan operasional masjid sendiri maka dibangun penginapan sebagai usaha yang menghasilkan. Di sini masjid bukan hanya organisasi masyarakat yang semata-mata mencari dana dari masyarakat kemudian diberikan ke masyarakat lagi. Masjid juga merupakan unit usaha yang memikirkan untung dan rugi untuk memenuhi kebutuhan operasional sehari-hari. Adanya usaha tersebut bukan berarti mengahalalkan segala cara untuk mendapat keuntungan, tetapi dengan mengejar keberkahan. Keberkahan datang ketika tidak adanya pihak yang dijatuhkan dalam hal usaha adalah usaha yang dimiliki jamaah. Sehingga takmir memilih usaha yang berbeda. Maka jelas di sini takmir berorientasi pada pelayanan jamaah. 


\section{Pertanggungjawaban Pengelolaan Masjid pada Aspek Fisik}

Hasil reduksi terkait QSR Nvivo pada aspek fisik sebagai berikut:

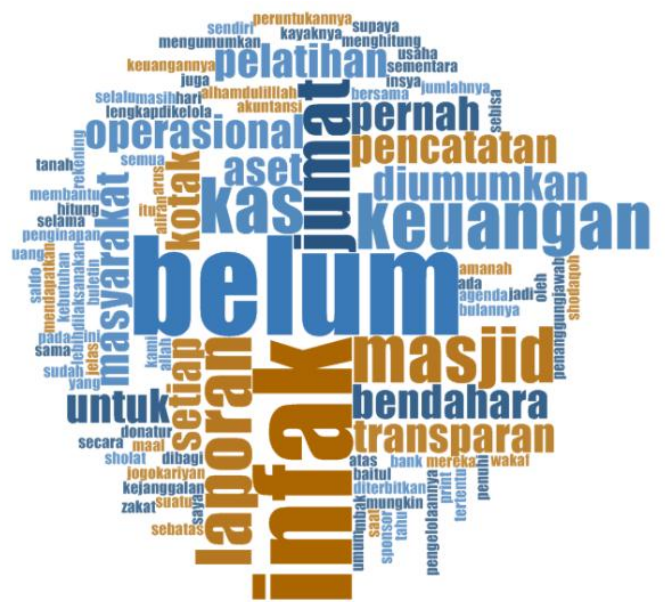

Gambar 2. Word Frequency Query QSR Nvivo pada aspek fisik

Selanjutnya poin penting hasil reduksi dituliskan pada tabel 2 .

Tabel 2. Poin penting hasil reduksi QSR Nvivo 12 menurut aspek fisik:

\begin{tabular}{|c|c|}
\hline Indikator & Poin Penting \\
\hline $\begin{array}{l}\text { Sumber Penerimaan } \\
\text { dan Pengeluaran } \\
\text { Masjid }\end{array}$ & $\begin{array}{l}\text { Infak jamaah dan unit usaha } \\
\text { Aktivitas operasional dan program kemasyarakatan }\end{array}$ \\
\hline $\begin{array}{l}\text { Basis Akuntansi } \\
\text { Masjid }\end{array}$ & $\begin{array}{l}\text { Pencatatan asset belum dilaksanakan } \\
\text { Arus Kas } \\
\text { Transparansi Laporan Keuangan (LK) }\end{array}$ \\
\hline $\begin{array}{l}\text { Laporan Keuangan } \\
\text { Masjid }\end{array}$ & $\begin{array}{l}\text { Bendahara membuat LK } \\
\text { Belum ada pelatihan akuntansi } \\
\text { Pelaporan arus kas } \\
\text { Publikasi saldo infak setiap Jum'at }\end{array}$ \\
\hline
\end{tabular}

Poin-poin pada Tabel 2 dapat diinterpretasikan bahwa kemandirian dan transparansi merupakan kunci utama kelangsungan hidup masjid. Kelangsungan hidup masjid Jogokariyan didasari dari jalannya aktivitas masjid.Untuk menjalankan aktivitas masjid baik operasional maupun program kemasyarakatannya, dibutuhkan adanya pengelolaan keuangan yang baik. Pengelolaan keuangan masjid Jogokariyan mengedepankan kemandirian dan transparansi. Mandiri di sini maksudnya operasional masjid tidak ingin menjadi beban masyarakat. Sehingga dalam mengumpulkan dana yang dibutuhkan untuk masjid sendiri, dibangunlah usaha penginapan. Untuk menjalankan program yang terkait dengan masyarakat, masjid membuat sebuah gerakan menyadarkan masyarakat untuk berinfak yaitu Gerakan Jamaah Mandiri. Berikut poin-poin penting hasil reduksi terkait dengan aspek fisik:

Poin 1-2 menunjukkan bahwa penerimaan masjid berasal pihak internal dan eksternal.Penerimaan dari internal masjid yaitu unit usaha yang dimiliki masjid seperti penginapan, guest house. Penerimaan ekternal yaitu dari jamaah yang terdiri dari infak, zakat, shodaqoh, wakaf tanah masjid, donatur, sponsor. Penerimaan internal dari usaha masjid digunakan untuk membiayai operasional masjid seperti listrik, air, gaji karyawan dan lainnya.Sehingga operasional masjid tidak menjadi beban masyarakat.Penerimaan eksternal yang sumbernya dari jamaah maka diperuntukkan untuk jamaah.Masjid hanya sebagai fasilitator para donator untuk menyumbangkan rezekinya melalui program-program kemasyarakatan 
masjid.Namun bukan berarti hasil usaha masjid semata-mata hanya untuk pengeluaran operasional saja, tetapi juga untuk menyenangkan para jamaah.Jadi, tanpa adanya infak dari jamaah pun masjid tetap dapat menjalankan kegiatannya dari hasil usaha masjid itu sendiri.

Poin 3-5 berisi mengenai basis akuntansi masjid Jogokariyan.Pelaporan keuangan hanya sebatas arus kas masuk dan kas keluar masjid.Untuk asset masjid juga belum ada pencatatannya.Laporan keuangan yang dibuat selalu diterbitkan di Buletin Idul Fitri dan Idul Adha.Hal ini mencerminkan adanya transparansi dalam pengelolaan keuangan masjid.Tidak ada yang ditutup-tutupi.Rincian penerimaan dari donator semua ada di laporan keuangan. Begitu pula pengeluarannya untuk apa saja terlihat jelas. Mereka mengedepankan transparansi karena merupakan bentuk tanggungjawab mereka mengelola dana yang diamanatkan oleh jamaah. Selain itu juga untuk menjaga kepercayaan internal pengurus juga para jamaah.

Poin 6-9 berisi mengenai laporan keuangan masjid Jogokariyan.Setiap pos penerimaan memiliki penanggungjawab yang berbeda-beda.Para penanggungjawab menghitung tiap pos (tiap kotak infak) setiap Jum'at lalu melaporkan aliran kas masuk setiap hari Jum'at melalui whatsapp grup.Penghitungan dilakukan secara terbuka di masjid.Jadi siapapun berhak tau saldo yang dimiliki masjid.Kemudian di akhir bulan bendahara merekap penerimaan dan pemasukannya menjadi laporan keuangan.Pengelola keuangan masjid belum pernah mengikuti pelatihan akuntansi karena mereka masih fokus manajemen masjid. Menurut mereka yang terpenting adalah laporan keuangan tersebut mudah dibaca, jelas dan transparan.

Hasil reduksi mengartikan bahwa kemandirian menjadi prinsip kelangsungan hidup masjid karena adanya gerakan mandiri menyadarkan masyarakat untuk berinfak dan usaha yang dimiliki masjid. Sehingga pelaksanaan program masjid tidak akan membebani masyarakat. Pencatatan keuangan masjid memang belum menerapkan prinsip akuntansi yang ada pada PSAK 45 dan PSAK 109, namun arwah dari PSAK 45 dan PSAK 109 yang mengedepankan transparansi sudah diterapkan oleh takmir.

Pertanggungjawaban Pengelolaan Masjid pada Aspek Spiritual

Hasil reduksi terkait QSR Nvivo pada aspek spiritual sebagai berikut:

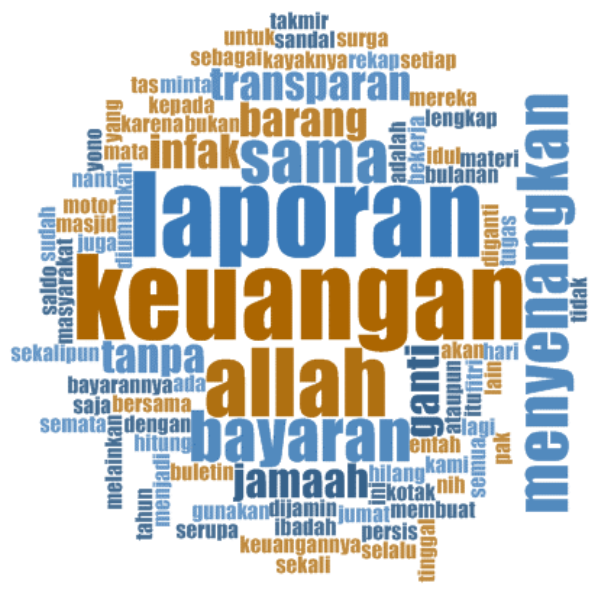

Gambar 2. Word Frequency Query QSR Nvivo pada aspek spiritual

Selanjutnya poin penting hasil reduksi dituliskan pada tabel 3.

Tabel 3. Poin penting hasil reduksi QSR Nvivo 12 menurut aspek spiritual

\begin{tabular}{ll}
\hline \multicolumn{1}{c}{ Indikator Etika Syariah } & \multicolumn{1}{c}{ Poin Penting } \\
\hline \multirow{2}{*}{ Tauhid } & $\begin{array}{l}\text { Bekerja semata-mata karena Allah } \\
\text { Tanpa upah }\end{array}$ \\
\hline \multirow{2}{*}{ Tanggung jawab } & $\begin{array}{l}\text { Transparan } \\
\text { Adanya laporan keuangan }\end{array}$ \\
\hline \multirow{2}{*}{ Ihsan } & $\begin{array}{l}\text { Upaya menyenangkan jamaah } \\
\text { Penggantian barang serupa }\end{array}$ \\
\hline
\end{tabular}

Poin-poin pada Tabel 3 dapat diinterpretasikan sebuah keikhlasan menjadi seorang takmir. Menjadi seorang takmir bukanlah pekerjaan yang mudah. Seorang takmir mengemban amanat 
dari Allah untuk menjadi pelayan di rumah-Nya. Poin 1-2 menunjukkan bahwa takmir bekerja semata-mata karena Allah. Pekerjaan takmir adalah pekerjaan utama mereka yang bayarannya bukan uang melainkan pahala dari Allah SWT. Meskipun mereka memiliki profesi di luar takmir, mereka tetap memprioritaskan mengelola masjid sebagai pekerjaan utama mereka.

Poin 3-4 berisi mengenai tanggung jawab takmir. Para takmir telah melaksanakan prinsip tanggung jawab dengan mengumumkan saldo yang ada pada setiap kotak infak di depan jamaah secara transparan. Pelaporan keuangannya juga sangat lengkap di bulletin berisi rincian kas masuk dan kas keluar sehingga semua orang dapat mengawasi pengelolaan keuangan masjid. Untuk setiap penanggungjawab yang melaporkan aliran kas keluar juga selalu menyertakan bukti untuk apa kas tersebut dikeluarkan.

Poin 5-6 berisi mengenai sifat ihsan yang dimiliki takmir.Kesejahteraan umat adalah motivasi takmir dalam mengelola masjid. Takmir selalu berusaha menyenangkan hati para jamaah dengan cara mensejahterakan mereka, memberikan apa yang masyarakat butuhkan. Mereka selalu berusaha membuat masyarakat merasa nyaman dan aman berada di masjid.Salah satu contohnya adalah dengan menjamin keamanan semua barang milik jamaah di masjid. Apabila ada barang yang hilang akan diganti dengan barang yang serupa. Semua dilakukan takmir untuk membuat jamaah percaya pada masjid.Sehingga jamaah pun tidak merasa canggung dan tegang ketika berada di masjid.

Hasil reduksi mengartikan bahwa menjadi seorang takmir adalah pekerjaan yang pertanggung jawabannya tidak hanya kepadamanusia saja melainkan kepada Allah. Meskipun tidak mendapat bayaran secara materi dari masjid namun takmir tetap mempertanggungjawabkan pekerjaannya dalam mengelola masjid. Kualitas jamaah merupakan prioritas takmir. Takmir berusaha menyenangkan jamaah dengan memberikan apa yang mereka butuhkan tanpa adanya harapan timbal balik dari jamaah (ihsan). Sehingga menjadi seorang takmir adalah pekerjaan yang penuh dengan keikhlasan.

\section{KESIMPULAN}

Berdasarkan hasil penelitian, pertanggungjawaban pengelolaan masjid Jogokariyan pada aspek mental telah terpenuhi dengan tercapai-nya program-program sesuai aturan yang ada. Laporan setiap program dimuat di bulentin masjid yang diterbitkan di Idul Fitri dan Idul Adha.Pertanggungjawaban pengelolaan masjid pada aspek fisik memang belum sepenuhnya terpenuhi.Takmir tidak mengenal PSAK 45 maupun PSAK 109.Bendahara sebatas mencatat arus kas masuk dan kas keluar saja, meskipun sudah sangat jelas dan transparan.Tercapainya program-program masjid juga didukung dengan tercapainya pertanggungjawaban pengelolaan masjid pada aspek spiritual.Takmir dengan sepenuh hati semata-mata karena Allah melayani jamaah.Mereka bekerja tidak mengharapkan imbalan apapun di dunia melainkan mendapat imbalan berupa pahala dari Allah SWT. Ketiga aspek sangatlah penting, kinerja mental dapat tercapai ketika adanya keseimbangan antara kinerja fisik dan kinerja spiritual.

\section{IMPLIKASI}

Implikasi dari kesimpulan di atas adalah agar kedepan dapat dibuat laporan ketercapaian program masjid yang memuat prosentase ketercapaiannya. Sehingga laporan tersebut dapat menjadi acuan untuk menjalankan program selanjutnya dan dapat menemukan solusi atas hambatan yang ada. Takmir masjid juga sebaiknya mengikuti pelatihan akuntansi untuk memperbaiki laporan keuangan yang dibuat karena masjid bukan hanya organisasi nirlaba saja melainkan juga sebuah entitas bisnis. Perlu adanya pelaporan keuangan yang baik sesuai dengan standar akuntansi yang berlaku agar kelangsungan usaha masjid dapat berjalan lancar. Untuk aspek spiritual alangkah lebih baik jika dibuat laporan akuntansi syariah yang berisi Laporan Komitmen Tauhid, Laporan Rahmat Allah dan Laporan Amanah Allah (Triyuwono, 2011). Laporan tersebut berfungsi sebagai doa dan zikir yang dapat mengubah sirkuit sistem syaraf otak para pengguna untuk membentuk citra Allah dan perilaku positif seperti yang terkandung dalam laporan tersebut. 


\section{DAFTAR PUSTAKA}

Adlan, Aqim M. (2010). Perbandinan antara Akuntansi Konvensional dan Akuntansi Syariah. Artikel Keislaman.

Ellwood, Sheilla. 1993. Parish Town and Councils: Financial Accountability and Management. Local Government Studies. Vol 19.

Harsono. (2008). Etnografi Pendidikan sebagai Desain Penelitian Kualitatif. Surakarta: Muhammadiyah University Press.

Ikatan Akuntansi Indonesia. (2008). Pernyataan Standar Akuntansi Keuangan (PSAK) No. 45. Dewan Standar Akuntansi Keuangan: Jakarta.

Ikatan Akuntansi Indonesia. (2008). Pernyataan Standar Akuntansi Keuangan (PSAK) No. 109. Dewan Standar Akuntansi Keuangan: Jakarta.

Mardiasmo. (2002). Akuntansi Sektor Publik. Yogyakarta: Andi.

Miles, Mattew B dan Amichael Huberman. (2007). Analisis Data Kualitatif Buku Sumber tentang Metode-Metode Baru. Terjemahan Tjetjep Rohendi Rohisi. Jakarta: Universitas Indonesia.

Sugiyono. (2010). Metode Penelitian Pendidikan Pendekatan Kuantitatif, Kualitatif, dan R\&D. Bandung: Alfabeta.

Sutama. (2010). Metode Penelitian Pendidikan. Cetakan pertama. Surakarta: Fairuz Media.

Triyuwono, I dan Roekhudin. (2000). Konsistensi Praktik Sistem Pengendalian Intern dan Akuntabilitas Pada Lazis (Studi kasus di Lazis X Jakarta). Jurnal Penelitian Akuntansi Indonesia. Vol 3 No 2.

(simas.kemenag.go.id) 